\title{
ТРАНСПОРТНОЕ ОБЕСПЕЧЕНИЕ КАК ФАКТОР ИНВЕСТИЦИОННОЙ ПРИВЛЕКАТЕЛЬНОСТИ АРКТИЧЕСКИХ РЕГИОНОВ
}

\section{(c) 2019 Меркулина Ирина Анатольевна}

доктор экономических наук, профессор кафедры «Экономика организации» Финансовый университет при Правительстве Российской Федерации, Россия, Москва E-mail: IAMerkulina@fa.ru

\section{(c) 2019 Харитонова Татьяна Викторовна}

кандидат экономических наук, доцент кафедры «Экономика организации» Финансовый университет при Правительстве Российской Федерации, Россия, Москва E-mail: TVHaritonova@fa.ru

\section{(c) 2019 Зайцев Сергей Петрович}

кандидат экономических наук,

заместитель декана Факультета экономики и финансов топливно-энергетического комплекса Финансовый университет при Правительстве Российской Федерации, Россия, Москва

\section{E-mail: SPZajtsev@fa.ru}

Статья подготовлена по результатам научных исследований, выполненных за счет бюджетных средств по государственному заданию Финуниверситету в 2019 году. В статье рассмотрены основные показатели транспортного обеспечения Арктических регионов в разрезе автомобильного, железнодорожного, водного, а также авиатранспорта, обусловлена их связь с формированием инвестиционной привлекательности территории, даны рекомендации по развитию экономики в данных регионах.

Ключевые слова: транспортное обеспечение, виды транспорта, Арктические регионы, инвестиционная привлекательность

Арктические регионы представляют собой особую территорию Российской Федерации, для которой характерны уникальные экономические, экологические, социальные и геополитические условия, оказывающие влияние на формирование механизмов инвестиционной привлекательности арктических проектов. Специфика транспортного обеспечения неодинакова для каждой из входящих в Арктическую зону территорий и зависит от равномерности освоения и развития территорий, их удаленности от основных промышленных центров, наличия достаточной транспортной и логистической инфраструктуры.

Вместе с тем, инвестиционная привлекательность удаленных регионов Арктической зоны в значительной степени определяется уровнем развития транспортного обеспечения, включающего оснащенность территории автомобильным, железнодорожным, водным, а также авиатранспортом.

Количество автомобильных дорог, имеющих твердое покрытие и находящихся в общем поль- зовании в общей протяженности дорог общего пользования приведено на рисунке 1 [1].

Наиболее сильное снижение количества автомобильных дорог общего пользования с твердым покрытием с 2005 по 2017 годы было зафиксировано в Архангельской области $(24,7$ п.п.), Республике Сахе (Якутия) (12,3 п.п.), Красноярском крае (11,9 п.п.), Ненецком автономном округе (7,5 п.п.), Ямало-Ненецком автономном округе (7,1 п.п.), Республике Карелии (5,7 п.п.), Республике Коми (1,3 п.п.), Мурманской области (1 п.п.). Незначительное увеличение (7,9 п.п) было зафиксировано лишь в Чукотском автономном округе.

Вместе с тем, увеличение количества автомобильных дорог общего пользования с усовершенствованным покрытием было зафиксировано за аналогичный временной период в Республике Сахе (Якутия) (8,5 п.п.), Чукотском автономном округе (4,8 п.п.), Мурманской области $(4,1$ п.п.), Ненецком автономном округе $(0,4$ п.п.). Снижение данного показателя было наиболее очевидным в Красноярском крае (5,4 п.п.), 


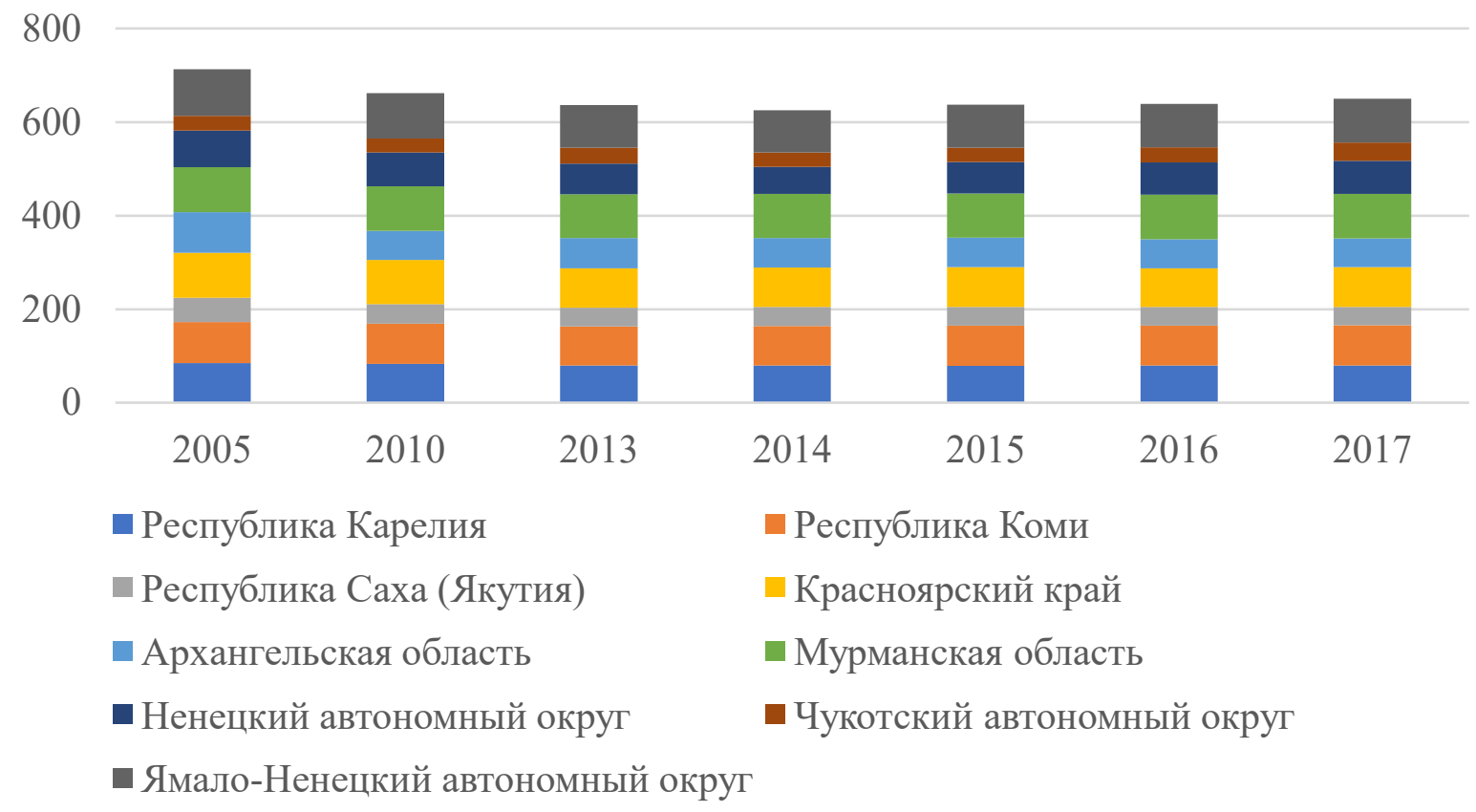

Puc. 1. Количество автомобильных дорог общего пользования с твердым покрытием, \%

Республике Коми (3 п.п.), Архангельской области (0,6 п.п.), Ямало-Ненецком автономном округе (0,6 п.п.).

Увеличение плотности автомобильных дорог общего пользования с твердым покрытием было зафиксировано во всех Арктических регионах.

Увеличение количества автобусов общего пользования было зафиксировано за аналогичный временной период в Республике Карелии (69 шт.), Республике Коми (49 шт.), Красноярском крае (36 шт.), Архангельской области (20 шт.), Мурманской области (24 шт.), Ненецком автономном округе (41 шт.). Снижение данного показателя было наиболее очевидным в ЯмалоНенецком автономном округе (141 шт.), Чукотском автономном округе (12 шт.), Республике Сахе (Якутии) (1 шт.).

Снижение числа дорожно-транспортных происшествий произошло почти во всех регионах, за исключением Республики Саха (Якутия) и Чукотского автономного округа, при этом абсолютное снижение числа погибших в дорожнотранспортных происшествиях было зафиксировано во всех регионах Арктической зоны без исключения.

Снижение числа перевозок пассажиров наиболее сильно коснулось Красноярского края, где данный показатель уменьшился почти в два раза: с 449,2 до 223,3 млн. чел. Аналогичная картина двукратного снижения наблюдалась в Ненецком автономном округе и в Ямало-Ненецком автономном округе.
Пассажирооборот автобусов общего пользования увеличился в Республике Карелия и в Республике Саха (Якутия) на 340 и 157 млн. пасс. км соответственно. В остальных регионах наблюдалось снижение данного показателя.

Данные об отправлении грузов и пассажиров железнодорожным транспортом общего пользования приведены на рисунках 2 и 3.

Перевозки грузов общего пользования железнодорожным транспортом увеличилось в Республике Карелия (8,9 млн. т), Республике Саха (Якутия) (3,4 млн. т), Красноярском крае (6 млн. т) и Мурманской области (2,1 млн. т), уменьшилось в Республике Коми (8,9 млн. т) и в Архангельской области (4,9 млн. т). В Ненецком и Чукотском автономных округах наличие железнодорожного транспорта не зафиксировано.

Отправление пассажиров железнодорожным транспортом уменьшилось во всех регионах Арктической зоны за исключением ЯмалоНенецкого автономного округа. Плотность железнодорожных путей оставалась неизменной на протяжении рассматриваемого периода.

Учитывая проблему транспортной доступности, наиболее эффективным видом транспорта выступает авиатранспорт, обладающий высокими показателями скорости доставки грузов и пассажиров в удаленные районы Арктической зоны. Основными видами авиаинфраструктуры являются грунтовые аэродромы, авиаплощадки, аэродромы с искусственным покрытием, аэродромы с системами светосигнального обо- 


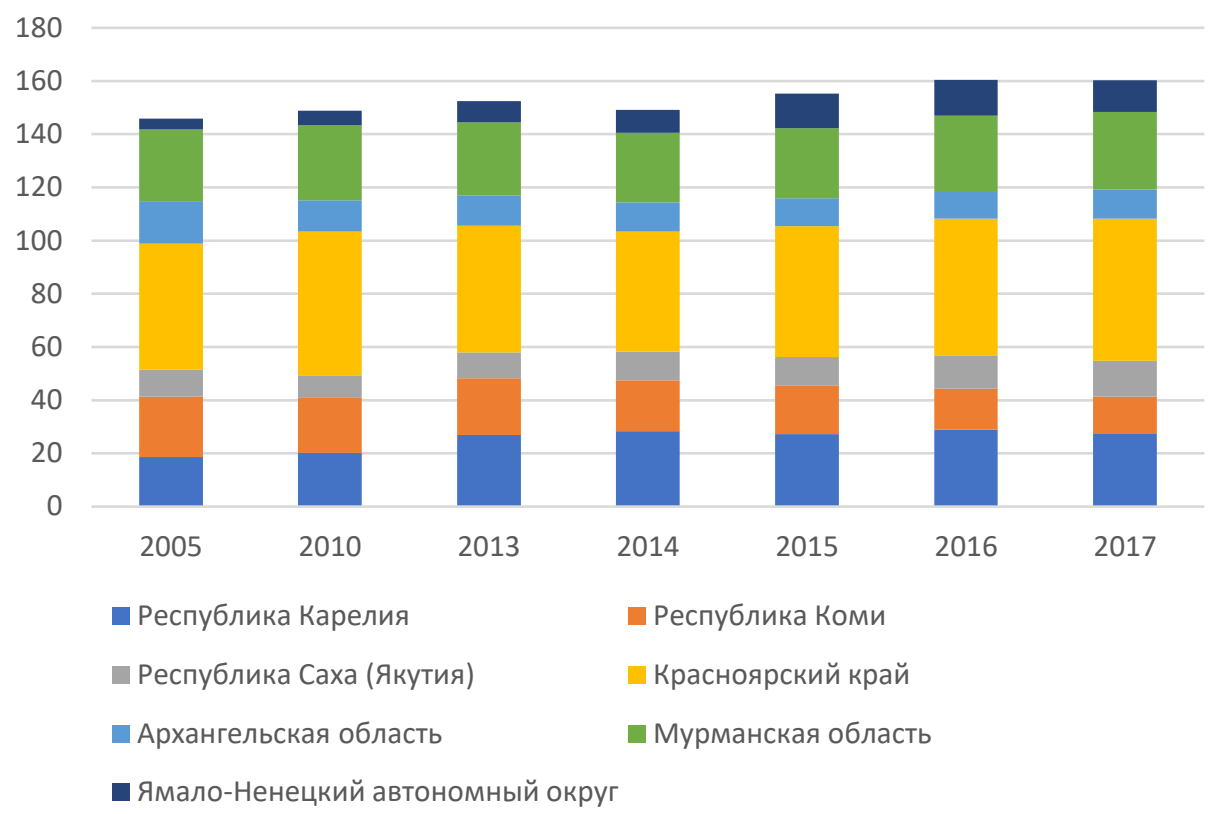

Puc. 2. Перевозки грузов железнодорожным транспортом общего пользования, млн. т.

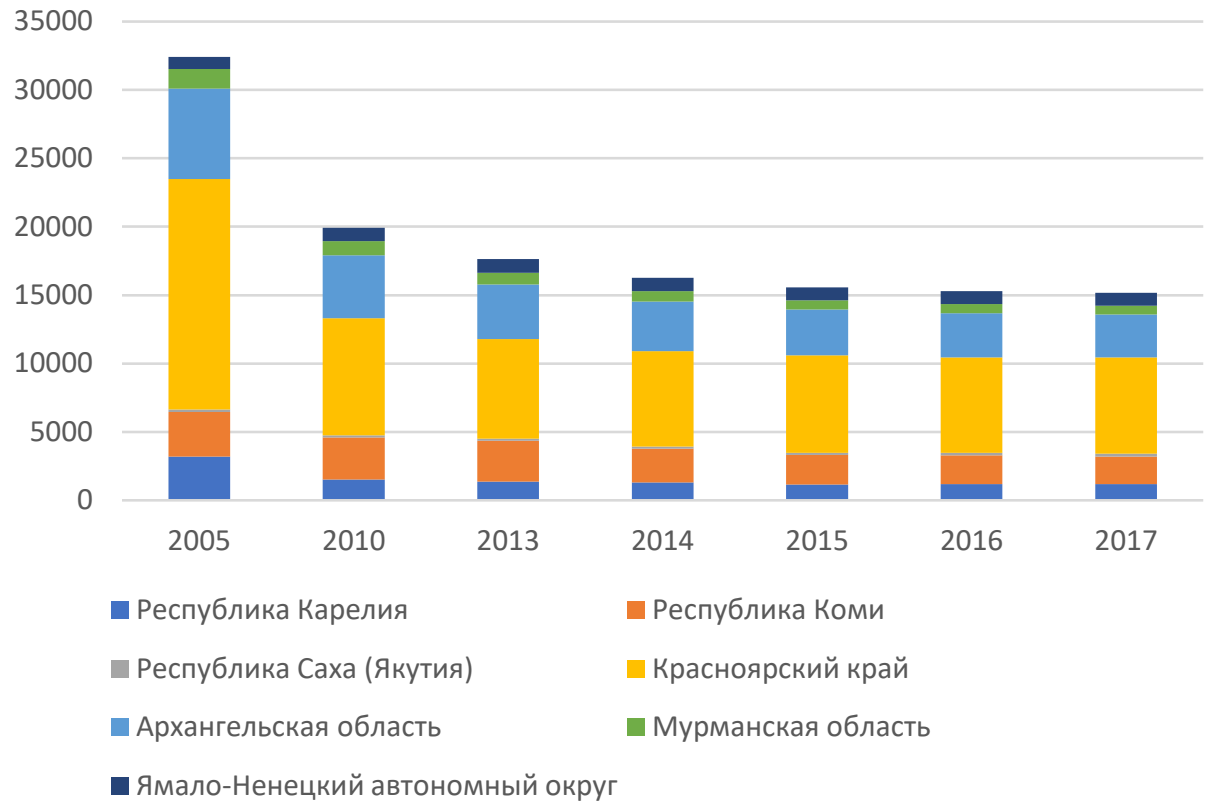

Рис. 3. Отправление пассажиров железнодорожным транспортом, тыс. чел.

рудования, которые контролируются в рамках казенных предприятий: «Аэропорты Севера», «Аэропорты Чукотки», «Аэропорт Амдерма» и «Аэропорты Красноярья» [2].

В Мурманской области действует 3 аэропорта: Мурманск, Хибины и Ловозеро. На территории Республики Карелия действуют 2 аэродрома и 7 посадочных площадок. На территории Ямало-Ненецкого автономного округа находится 7 аэропортов, осуществляющих приём и отправку пассажиров, почты и грузов по межмуниципальным и межрегиональным направлениям. На территории Архангельской области расположены 23 аэропорта (аэродрома), из них 7 аэропортов имеют аэродромы с искусственным покрытием. В Республике Коми авиатранспортное сообщение находится в ведении ФГУП «Комиавиатранс». Как основные следует отметить аэропорты «Сыктывкар», «Воркута», «Ухта», «Печора», «Усинск», «Инта» и «Усть-Цильма». В 
Ямало-ненецком автономном округе действует аэропорт «Салехард», «Ноябрьск», «Новый Уренгой», «Надым». В Красноярском крае осуществляет деятельность 61 аэродром. На территории Якутии размещено три аэропорта государственного значения (Якутск, Тикси, Чокурдах), 35 аэродромов (включая неиспользуемые) местных воздушных линий и 195 посадочных площадок. В Чукотском автономном округе действует аэропорт «Анадырь» и 9 аэропортов местного значения.

Основные характеристики водного (речного и морского) транспорта в Арктических регионах представлены в таблице 1.

Анализ транспортного обеспечения Арктической зоны показывает, что наибольшую роль в виде используемого транспорта играет территориальная специфика региона, его близость/удаленность от основных объектов транспортной инфраструктуры.

Среди других наиболее важных показателей следует выделить уровень развития жилищнокоммунального хозяйства, в том числе энергоснабжения регионов Арктической зоны, уровень загрязнения территории, уровень оказания государственных и муниципальных услуг, медицинское обслуживание населения.

Рекомендации по приоритетному развитию транспортного обеспечения Арктических регионов в целях повышения их инвестиционной привлекательности заключаются в развитии инфраструктурных проектов в различных видах транспорта, в том числе с приоритетом использования возможностей Северного Морского пути (например, для Ямало-Ненецкого автономного округа строительство железной дороги «Северный широтный ход» с выходом на СМП), с привлечением различных источников финансирования, в том числе государственно-частного партнерства. Также в Арктических регионах существует потребность в совершенствовании инвестиционной политики, направленной на повышение инвестиционной привлекательности региона, привлечении долгосрочных, в том числе иностранных инвестиций в транспортные проекты, снижении политических и экономических рисков при их реализации.

Таблица 1. Основные характеристики водного (речного и морского) транспорта в регионах Арктической зоны

\begin{tabular}{|c|c|c|}
\hline \multirow{2}{*}{$\begin{array}{c}\text { Регион, входящий в } \\
\text { АЗРФ }\end{array}$} & \multicolumn{2}{|c|}{ Водный транспорт } \\
\hline & Речной транспорт & Морской транспорт \\
\hline Мурманская область & \multicolumn{2}{|c|}{ Три морских порта - Мурманск, Кандалакша, Витино. } \\
\hline Республика Карелия & $\begin{array}{l}\text { Скоростные теплоходы с подводными } \\
\text { крыльями, социальные скоростные линии }\end{array}$ & $\begin{array}{l}\text { Три регулярные морские линии, которые } \\
\text { проложены по акватории Белого моря: } \\
\text { Беломорск - Соловки, } \\
\text { Кемь (Рабочеостровск) - Соловки, } \\
\text { Чупа - о. Средний - Кереть. }\end{array}$ \\
\hline $\begin{array}{c}\text { Ненецкий } \\
\text { автономный округ }\end{array}$ & \multicolumn{2}{|c|}{$\begin{array}{l}\text { АО «Северречфлот» (межмуниципальные и межрегиональные маршруты) } \\
\text { ИП Сандулов С.Г. (паромная переправа Салехард - Приобье) } \\
\text { Обь-Иртышское речное пароходство сайт (паромная переправа Салехард - Приобье) }\end{array}$} \\
\hline $\begin{array}{c}\text { Архангельская } \\
\text { область }\end{array}$ & \multicolumn{2}{|c|}{$\begin{array}{l}50 \text { переправ и } 10 \text { транспортных операторов } \\
\text { Самые крупные по объемам перевозимых грузов и пассажиров: } \\
\text { OАО «Северное речное пароходство», } \\
\text { OАО «Архангельский речной порт». }\end{array}$} \\
\hline Республика Коми & \multicolumn{2}{|l|}{$\begin{array}{l}\text { г. Печора - г. Вуктыл - г. Печора } \\
\text { с. Усть-Цильма - с. Ермица - с. Усть-Цильма } \\
\text { д. Чаркабож - п. Щельяюр - д. Чаркабож } \\
\end{array}$} \\
\hline $\begin{array}{l}\text { Ямало-Ненецкий } \\
\text { автономный округ }\end{array}$ & \multicolumn{2}{|l|}{ Морская навигация длится 3-4 месяца в году } \\
\hline Красноярский край & \multicolumn{2}{|l|}{$\begin{array}{l}\text { ОАО «Енисейское речное пароходство» } \\
\text { ОАО «Пассажирречтранс» }\end{array}$} \\
\hline $\begin{array}{l}\text { Республика Саха } \\
\text { (Якутия) }\end{array}$ & \multicolumn{2}{|c|}{ Скоростные суда на подводных крыльях «Метеор», «Восход», «Ракета», «Полесье». } \\
\hline $\begin{array}{c}\text { Чукотский } \\
\text { автономный округ }\end{array}$ & \multicolumn{2}{|l|}{\begin{tabular}{|l} 
Анадырский морской порт \\
Морской торговый порт Беринговский \\
Морской порт Провидения \\
Морской порт Эгвекинот \\
Морской порт Певек \\
\end{tabular}} \\
\hline
\end{tabular}




\section{Библиографический список}

1. Федеральная служба государственной статистики. URL: http://www.gks.ru

2. Грузинов В. М., Зворыкина Ю.В., Иванов Г.В., Сычев Ю.Ф., Тарасова О.В., Филин Б.Н., Арктика: экология и экономика. № 1 (33), 2019. С. - 6-20.

3. Харитонова Т.В. Оценка эффективности развития арктических территорий: социально-экономический аспект // Мониторинг. Наука и технологии. 2018. № S5. C. 52-57.

4. Харчилава Х.П., Сорокин Д.Д., Андреев Н.В., Топалов Р.В. Потенциал Северного морского пути Арктической зоны России // Мониторинг. Наука и технологии. 2018. № S5. С. 24-33.

5. Мясков А.В., Зайцев В.А., Петров И.В., Шмелев В.С. Системные особенности экологического мониторинга при формировании территориальных проектов северного морского пути // Мониторинг. Наука и технологии. 2018. № S5. С. 7-15.

6. Пухова М.M. Основные проблемы развития Северного морского пути // Мониторинг. Наука и технологии. 2018. № S5. C. 47-52. 